\title{
ISLAMIC WORK ETHIC AND SATISFACTION WITH INTRINSIC MOTIVATION AS MEDIATOR VARIABLES
}

\author{
Rio Eriawan Putra Tohari \\ Post Graduate Universitas Airlangga \\ rio-e-p-10@feb.unair.ac.id
}

\author{
Ririn Tri Ratnasari \\ Post Graduate Universitas Airlangga \\ ririnsari@feb.unair.ac.id
}

\begin{abstract}
This study aims to determine the influence of the Islamic work ethic, intrinsic motivation and job satisfaction. This study employs quantitative approach. This study uses a sample of 30 respondents. The respondent of this study is employees at Bank Syariah Mandiri Darmo Branch in Surabaya who regularly works at least 3 years. The sampling technique is non-probability sampling. As for the technique analysis this study uses PLS (Partial Least Square). The results show that the Islamic work ethic is a significant influence on intrinsic motivation, Islamic work ethic is a significant influence on job satisfaction and intrinsic motivation is a significant influence to job satisfaction.
\end{abstract}

Keywords: Islamic Work Ethics, Intrinsic Motivation, Job Satisfaction

\section{INTRODUCTION}

Human Resources is one of the most valuable assets in an organization or company. Rivai, Veithzal and Basri (2005: 2) stated that human resources can create efficiency, effectivity, and productivity of the company. Therefore, it is very important for an organization or company in maintaining existing human resources. To achieve a good quality of human resources, the human resource management should take measures to develop the quality of human resources. As an effort to improve professionalism in the organization, the development of human resources has a broad dimension. The main purpose is to increase the potential possessed by human resources. In large-scale organizations, human resources are seen as a crucial element in the business development process. Thus, the role of human resources becomes increasingly important.

This paper discusses the work ethic of Islam in Islamic Bank. Bank is a business engaged in services. The work ethic of Islam in the company should be reflected in providing services to customers and employees. There is a need to give more motivation and education to create a good performance in their work. Islamic work ethics can be defined as a set of moral principles that distinguish the positive and the negative activities in the Islamic context.

From Islamic work ethics viewpoint, work fulfills the needs of human being for self-respect, satisfaction realization, and independent. Many people choose to stay in employment rather than being unemployed so that they can be independent and able to contribute to society (Salahudin, Baharuddin, Abdullah and Osman, 2015). Syariah Mandiri bank (BSM) develops and educates employees on an ongoing basis. BSM has a high commitment to improve the quality of Human Resources Management (HRM). This cannot be separated from the efforts of BSM leaders to always communicate the BSM Mission through HRM Development. Excellent human resource is the main support for the market leader and the locomotive of Syariah banking development in Indonesia. BSM develops a culture of continuous learning to create excellent human resource generations. It has been supported by the best learning facilities. Syariah Mandiri Bank at Darmo Branch Surabaya grows as a bank that able to integrate its operational activities with spiritual values. It was awarded as 'Number One Service' in Syariah bank until 2016.

\section{A. Effect of Intrinsic Motivation on Job Satisfaction}

Keaveney (1992: 177 in Karatepe, 2006: 177) explains that "intrinsic motivation refers to feelings of challenge or competition derived from doing a job". According to Pintrich and Schunk (1996) describes "an intrinsically motivated individual, perform an activity because of his own desires, so that from the activity he will gain selfsatisfaction". The empirical evidence is provided to support the relationship between intrinsic motivation and job satisfaction. Low and Cravens (2001) also found that "intrinsic motivation is positively related to salesperson satisfaction". Based on these theories, it can be concluded that intrinsic motivation has a positive correlation with job satisfaction.

\section{B. The Influence of Islamic Working Ethic on Employee Job Satisfaction}

Rokhman (2010) states that employees who pay attention to the value of work ethic of Islam will get job satisfaction. Conversely, if employees pay less attention to the value of work ethic of Islam then job satisfaction will be difficult to obtain (Hayati, 2012). Aldulaimi (2016) states that by practicing Islamic working ethic, it will lead to better work performance, such as improving the confidence and satisfaction level, placing organizational needs greater than individual needs, and experiencing the feeling of peace and tranquility at the workplace. Therefore, it is important to 
instill Islamic working ethic in organizational practices in any country.

Based on these theories, it can be concluded that the work ethic of Islam has a positive correlation with job satisfaction. Job satisfaction in this research includes employee job satisfaction. The reason is the company usually only pays attention to the output rather than pay attention to its employees.

When the leadership gives input, and invites employees to share the existing problems at the office, the employee feels that the company recognizes their voices.

There are 3 theories support this study, they are, theory of the influence of the work ethic of Islam on intrinsic motivation by Asifudin (2004: 34), the influence of intrinsic motivation on job satisfaction by Pintrich and Schunk (1996) and the influence of the work ethic of Islam on job satisfaction by Rokhman (2010).

\section{Conceptual Framework}

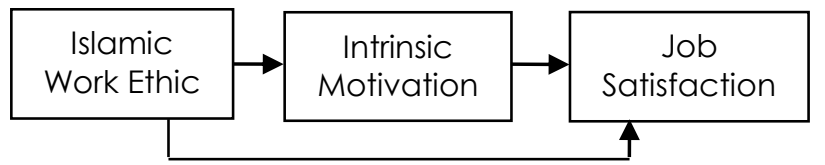

\section{RESEARCH METHOD}

\section{A. Methodology and Sampling Method}

This research employed qualitative methodology. The procedure of determining the sample used non-probability sampling method. It is a sampling method where all the individuals in the population have equal opportunity to be assigned to the sample member. The number of samples in accordance with the guidelines in Wibisono (2000) which explains that in multivariate processing the massive sample used 5-10 times of the number of variables. Based on these criteria, the sample size in the study is 10 times of the number of variables. The number of respondents were 30 respondents. The criteria of respondents are permanent employees of Mandiri Syariah Bank at Darmo Branch which has been working for at least 3 years.

\section{B. Partial Least Square (PLS)}

PLS is an alternative method of Structural Equation Modeling (SEM) that can be used to overcome relationship problems of complex variables, but it has small sample size data (30 to 100). Meanwhile, SEM has a minimum sample size of 100 (Hair and Starstedt, 2010).

\section{RESULT}

\section{A. Results of PLS Analysis Testing Measurement Model (Outer Model)}

The Outer Model is a model that specifies the relationship between latent variables and their indicators. In other words, the outer model defines how each indicator relates to its latent variables (Ghozali, 2008: 22).

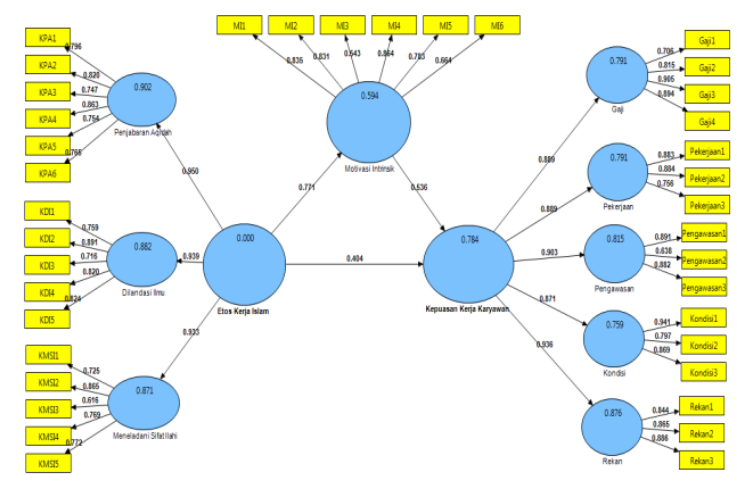

\begin{tabular}{|c|c|c|c|}
\hline Variable & $\begin{array}{c}\text { Latent } \\
\text { Variable }\end{array}$ & $\overline{\mathrm{AVE}}$ & Note \\
\hline \multirow[t]{4}{*}{$\begin{array}{c}\text { Islamic Work } \\
\text { Ethic } \\
\end{array}$} & - & 0.520616 & Valid \\
\hline & $\begin{array}{l}\text { Work is aqidah } \\
\text { implementation }\end{array}$ & 0.600355 & Valid \\
\hline & $\begin{array}{l}\text { Work based on } \\
\text { knowledge }\end{array}$ & 0.613698 & Valid \\
\hline & $\begin{array}{c}\text { Work by } \\
\text { examining the } \\
\text { divine attributes } \\
\text { and follow his } \\
\text { guidelines }\end{array}$ & 0.561986 & Valid \\
\hline $\begin{array}{l}\text { Intrinsic } \\
\text { Motivation }\end{array}$ & - & 0.594385 & Valid \\
\hline \multirow[t]{6}{*}{$\begin{array}{c}\text { Working } \\
\text { Satisfaction }\end{array}$} & - & 0.525066 & Valid \\
\hline & Salary & 0.684284 & Valid \\
\hline & The job itself & 0.693976 & Valid \\
\hline & Monitoring & 0.602515 & Valid \\
\hline & $\begin{array}{l}\text { Working } \\
\text { condition }\end{array}$ & 0.766324 & Vali \\
\hline & Co-workers & 0.737394 & Valid \\
\hline
\end{tabular}

The table shows the value of AVE on each variable and indicator in the analysis model of this study has a good construct validity because AVE is greater than 0.5 . 


\section{Discriminant Validity}

Construct is said to have good discriminant validity if cross-load correlation value of certain construct with indicator is higher than another construct (Ghozali, 2008).

\section{Composite Reliability}

\begin{tabular}{|c|c|c|c|}
\hline \hline Variable & $\begin{array}{c}\text { Latent } \\
\text { Variable }\end{array}$ & AVE & Note \\
\hline $\begin{array}{c}\text { Islamic } \\
\text { Work Ethic }\end{array}$ & - & 0.949815 & Reliable \\
\hline & $\begin{array}{c}\text { Work is aqidah } \\
\text { implementation }\end{array}$ & 0.909647 & Reliable \\
\hline $\begin{array}{c}\text { Work based on } \\
\text { knowledge }\end{array}$ & 0.901066 & Reliable \\
\hline $\begin{array}{c}\text { Work by } \\
\text { examining the } \\
\text { divine attributes } \\
\text { and follow his } \\
\text { guidelines }\end{array}$ & 0.866711 & Reliable \\
\hline $\begin{array}{c}\text { Intrinsict } \\
\text { Motivation }\end{array}$ & - & 0.890242 & Reliable \\
\hline $\begin{array}{c}\text { Work } \\
\text { Satisfaction }\end{array}$ & Salary & 0.900492 & Reliable \\
\hline & The job itself & 0.880109 & Reliable \\
\hline & Monitoring & 0.850379 & Reliable \\
\hline & Work condition & 0.903621 & Reliable \\
\hline & Co-workers & 0.899463 & Reliable \\
\hline
\end{tabular}

Based on the table, it can be seen that the composite reliability of each construct has a value of more than 0.7 , thus this model has met the composite reliability.

\begin{tabular}{|c|c|c|c|}
\hline Variabel & $\begin{array}{c}\text { Latent } \\
\text { Variable }\end{array}$ & AVE & Note \\
\hline \multirow[t]{4}{*}{$\begin{array}{c}\text { Islamic } \\
\text { Work Ethic }\end{array}$} & - & 0.943162 & Reliable \\
\hline & $\begin{array}{l}\text { Work is aqidah } \\
\text { implementation }\end{array}$ & 0.880372 & Reliable \\
\hline & $\begin{array}{l}\text { Work based on } \\
\text { knowledge }\end{array}$ & 0.862041 & Reliable \\
\hline & $\begin{array}{c}\text { Work by examine } \\
\text { the divine } \\
\text { attributes and } \\
\text { follow his } \\
\text { guidelines }\end{array}$ & 0.805480 & Reliable \\
\hline $\begin{array}{c}\text { Intrinsict } \\
\text { Motivation }\end{array}$ & - & 0.848333 & Reliable \\
\hline \multirow[t]{6}{*}{$\begin{array}{c}\text { Work } \\
\text { Satisfaction }\end{array}$} & - & 0.949022 & Reliable \\
\hline & Salary & 0.850266 & Reliable \\
\hline & The job itself & 0.795227 & Reliable \\
\hline & Monitoring & 0.733701 & Reliable \\
\hline & Work condition & 0.838366 & Reliable \\
\hline & Co-workers & 0.832446 & Reliable \\
\hline
\end{tabular}

This table shows that cronbach alpha from each construct has a value greater than 0.7 , this model has met the cronbach's alpha

\section{B. Structural Model (Inner Model)}

Inner model is a model that specifies the relationship among latent variables. In other words, inner model describes the relationship of latent variables based on substantive theory (Ghozali, 2008: 22).

\section{Determinant Coefficient $\boldsymbol{R}$ Square}

\begin{tabular}{|l|c|}
\hline \multicolumn{1}{|c|}{ Variable } & R Square \\
\hline Intrinsic motivation & 0,594249 \\
\hline Work satisfaction & 0,78427 \\
\hline \hline
\end{tabular}

Based on the table above, it is known that $\mathrm{R}$ square for intrinsic motivation variable is 0,594 which means intrinsic motivation influenced by work ethic of Islam equal to $59,4 \%$. While for job satisfaction having $\mathrm{R}$ square equal to 0,784 , it means that this variable influenced by intrinsic motivation equal to $78,4 \%$.

Parameter Coefficient

\begin{tabular}{|c|c|c|}
\hline \hline Variable Relationship & $\begin{array}{c}\text { Original } \\
\text { Sample } \\
\text { Estimate } \\
(\mathbf{O})\end{array}$ & $\begin{array}{c}\text { t Statistics } \\
(\mid \mathbf{O} \text { /STERR|) }\end{array}$ \\
\hline $\begin{array}{c}\text { Islamic Work Ethic -> Intrinsic } \\
\text { Motivation }\end{array}$ & 0.770875 & 8.162794 \\
\hline $\begin{array}{c}\text { Islamic Work Ethic -> Work } \\
\text { Satisfaction }\end{array}$ & 0.403623 & 3.174496 \\
\hline $\begin{array}{c}\text { Intrinsict Motivation -> Work } \\
\text { Satisfaction }\end{array}$ & 0.536306 & 3.969884 \\
\hline \hline
\end{tabular}

Path Coefficients

\begin{tabular}{|c|c|c|}
\hline \hline $\begin{array}{c}\text { Variable } \\
\text { Relationship }\end{array}$ & $\begin{array}{c}\text { t Statistics } \\
(\mid \mathbf{O} / \text { STERR } \mid)\end{array}$ & Note \\
\hline $\begin{array}{c}\text { Islamic Work Ethic -> } \\
\text { Intrinsict Motivation }\end{array}$ & 8.162794 & Significant \\
\hline $\begin{array}{c}\text { Islamic Work Ethic -> } \\
\text { Work Satisfaction }\end{array}$ & 3.174496 & Significant \\
\hline $\begin{array}{c}\text { Intrinsict Motivation -> } \\
\text { Work Satisfaction }\end{array}$ & 3.969884 & Significant \\
\hline \hline
\end{tabular}

\section{Discussion}

The results show that the work ethic of Islam has a significant influence on intrinsic motivation with the value of $t$ arithmetic $8.162794>1.96$. This suggests that the first hypothesis is acceptable.

The results showed that the work ethic of Islam has a significant influence on job satisfaction with the value of $t$ arithmetic $3.174496>1.96$.

The results showed that intrinsic motivation has a significant effect on job satisfaction with the value of $t$ count $3.969884>1.96$ 


\section{CONCLUSION}

The result of this study confirms nearly all the research hypothesis. The conclusion of this research can be drawn as follows:

1. Islamic work ethic significantly influences intrinsic motivation.

2. Islamic work ethic has a significant effect on job satisfaction.

3. Intrinsic motivation significantly influences to job satisfaction.

\section{REFERENCES}

[1] Aldulaimi, Saeed Hameed, "Fundamental Islamic perspective of work ethics", Journal of Islamic Accounting and Business Research, Vol. 7 Iss 1 pp. $59-76,2016$

[2] Asifudin, Ahmad Janan, Etos Kerja Islami, Surakarta: Muhammadiyah Unversity Press, 2004

[3] Beekun dalam Wahibur Rokhman, The Effect of Islamic Work Ethics on WorkOutcomes, EJBO, Vol. 15, No. 1, 2010, hal 345

[4] Ghozali, Imam, Aplikasi Analisis Multivariate dengan Progaram SPSS, Fourth Edition, Semarang: Badan Penerbit Undip, 2009.

[5] Hair, Joseph S. and Marko Sarstedt, A Primer on Partial Least Squares Structural Equation Modeling (PLS-SEM), Sage Publications, 2010.

[6] Hayati, Keumala and Indra Caniago, "Islamic Work Ethic: The role of Intrinsic Motivation, Job Satisfaction, Organizational Commitment and Job Performance", 2012, in press.

[7] Karatepe, Osman M. and Mehmet Tekinkus, "The effects of workfamily conflict, emotional exhaustion, and intirinsic motivation on job outcomes of front-line employes", Internasional Journal of Bank Marketing, Vol. 24, No. 3, pp. 173-193, 2006.

[8] Low, George S. and David W, Cravens, "Antecendents and consequences of salesperson burnout", European Journal of Marketing., Vol 35 No. 5/6, pp. 587-611, 2001.

[9] Pintrich, Paul R and Dale H. Schunk, Motivation in Education, Theory, Research, and Application, Ohio: Prenttice Hall, 1996.

[10] Rivai, Veithzal dan Basri, Performance Appraisal: Sistem yang Tepat Untuk Menilai Kinerja Karyawan dan Meningkatkan Daya Saing Perusahaan, Jakarta: PT Raja Grafindo Persada, 2005.

[11] Rokhman, Wakhibur, "The Effect of Islamic Work Ethics on Work Outcomes", Jurnal Vol. 15, No. 1., 2010.

[12] Salahudin, Shahrul Nizam bin, Siti Sarah binti Baharuddin, Muhammad Saffizal Abdullah and Abdullah Osman, "The Effect of Islamic Work Ethics on Organizational Commitment", Procedia Economics and Finance 35 ( 2016 ) 582 - 590, 2015

[13] Wibisono, Dermawan, Riset Bisnis, Yogyakarta: BPFE. 2000. 